Journal of Applied Veterinary Sciences, 7 (1): 11-17 (January, 2022).

ISSN: Online: 2090-3308, Print: 1687-4072

Journal homepage : https://javs.journals.ekb.eg

\title{
Investigation of The Association Between Bovine Viral Diarrhea Virus and Neospora caninum as a Cause of Abortion in Cattle
}

\author{
Rania S. El-Mohamady ${ }^{1}$ Gerges $^{2}$, A.A and Abd El-Hafeiz ${ }^{1}$, Y.G.M. \\ ${ }^{1}$ Viral Diseases Research Unit, Animal Reproduction Research Institute (ARRI), Agricultural Research Center \\ (ARC), Giza, Egypt. \\ ${ }^{2}$ Department of Reproductive Diseases, Animal Reproduction Research Institute (ARRI), Agricultural Research \\ Center (ARC), Giza, Egypt. \\ *Corresponding Author: Rania S. El-Mohamady, E-Mail: rania.elmohamdy@arc.sci.eg
}

\begin{abstract} Viral Diarrhea Virus (BVDV) and Neospora caninum (NC) in the induction of .2021 .98151 .1106 abortion in cattle. The study was carried out on 116 serum samples collected from 116 aborted cows in different Egyptian localities. All blood samples were immediately transported to the diagnostic laboratory. Serum was harvested after centrifugation at $1500 \times \mathrm{g}$ for $10 \mathrm{~min}$. All sera were divided equally into two microtubes and stored at $-20{ }^{\circ} \mathrm{C}$ until laboratory testing. Double antibody sandwich immunoenzymatic assay (DS.ELISA) is used for bovine viral diarrhea virus (BVDV) p80/p125 antigen detection and Anti-Neospora caninum (NC) antibodies were detected using an indirect ELISA. Our results cleared that the incidences of BVDV and NC among examined cow's serum samples were 66 $(56.9 \%)$, where the incidences of BVDV and NC were $31(26.72 \%)$ and 35 $(30.17 \%)$, respectively. There were $18(27.3 \%)$ samples that showed mixed infection BVDV and NC incidences among examined cattle serum samples. The study concluded that the prevalence of BVDV and NC are high and widely spread in cattle farms in Egypt. There is a pronounced association between BVDV and $\mathrm{NC}$ and concurrent infection in cattle farms in Egypt. So we should coordinate surveillance and control programs on abortifacient pathogens (BVDV and NC) should be developed and implemented, which would reduce the losses associated with these diseases in cattle farms.
\end{abstract}

Original Article:

This study aimed to investigate the complementary association between Bovine DOI:https://dx.doi.org/10.21608/javs

Received :01 October, 2021.

Accepted:17 November, 2021.

Published in January, 2022.

This is an open access article under the term of the Creative Commons Attribution 4.0 (CC-BY) International License. To view a copy of this license, visit:

http://creativecommons.org/licenses/by/4.0/

Keywords: Abortion, Bovine viral diarrhea virus (BVDV), Cattle, ELISA, Neospora caninum (NC).

J. Appl. Vet. Sci., 7 (1 ): 11-17.

\section{INTRODUCTION}

Abortion is critical to the dairy sector because it hinders heifers and cows' scheduled lactation and replacement. It also leads to culling, which has a negative impact on herd genetics, resulting in lower farm revenue. Furthermore, abortion storms can be psychologically devastating to the farmer. Many diseases cause cattle abortion as Campylobacteriosis, Leptospirosis, and Brucellosis (Carpenter et al., 2006 and Olmo et al., 2018). However, there is a scarcity of research on other additional diseases such as bovine viral diarrhea (BVD) and neosporosis as well as their interrelationships as causes of abortion. Nonetheless, these play a significant influence in reproductive wastage globally (Okumu, 2014 and Okumu et al., 2019).
Bovine viral diarrhea is considered one of cattle's most important viral diseases worldwide (Yitagesu et al., 2021). This is a Pestivirus in the family Flaviviridae closely related to the border disease virus of sheep and the classical swine fever virus of pigs (OIE, 2018). The virus has a wide distribution, and certain animals may have subclinical infections (Lindberg and Houe, 2005).

Bovine viral diarrhea virus is disseminated by direct contact with saliva, feces, semen, urine, tears and milk of infected cattle, as well as in utero infection of fetuses (Radostits et al., 1994 and Okumu et al., 2019), Early embryonic death, fetal death, and mummification are all possible outcomes of infection in naive pregnant cows and heifers (Okumu et al., 2019 and Yitagesu et al., 2021). 


\section{Investigation of the association between Bovine Viral Diarrhea Virus ......}

In South American dairy cattle herds, bovine viral diarrhea virus seropositivity rates of up to $70 \%$ $80 \%$ have been reported (Stahl et al., 2006). Prevalence rates in European and American herds have been reported to be between $21-98 \%$ in unvaccinated cattle herds (Waldner, 2005). In Africa, the disease has been found in a range of domestic and wild ruminants (Kabongo and Van Vuuren, 2004).

Neospora caninum (NC) is found all over the world and is one of the most frequent parasitic causes of abortion in cattle (Dubey and Schares 2011). The definitive hosts are domestic and wild canids (Gondim, 2006), and NC can infect a wide range of intermediate hosts, including bovine. Ingestion of food and/or water contaminated with oocytes shed in dog feces leads to cattle or congenital infection (Pan $\boldsymbol{e t}$ al., 2004 and Olum et al., 2020). NC is considered one of the main causes of cattle abortion.

Worldwide (Paradies et al., 2007; Silva et al., 2007). Neospora caninum causes abortions in calves as early as 3 months of pregnancy; however, they are most common around 5 and 6 months. One of the obvious evidence of infection of cattle is foetal resorption, autolysis, mummification, and stillbirth; however, some calves are born alive with neuromuscular problems and others appear healthy with persistently infected (Dubey and Schares, 2006).

Congenital/vertical transmission of neosporosis from seropositive dams to their offspring is prevalent, and abortion is common in future pregnancies (Dubey et al., 2007). Reported risk factors for bovine abortions due to Neospora caninum include geographical location, exposure to dogs, and being pregnant heifers (Dubey and Schares, 2006; Koiwai et al., 2006).

Neospora caninum is an intracellular protozoan parasite that is found globally and is a serious economic concern in the cattle sector. According to Fereig et al. (2016), N. caninum can result in abortion storms and a high culling rate. Also, there are currently no data on the prevalence of neosporosis in humans or animals in Southern Egypt. Concurrent infection with the Bovine Viral Diarrhea Virus (BVDV) has also been suggested as a contributing factor to $N$. caninuminduced miscarriage in cattle in recent research in the Philippines (Konnai et al., 2008 and Okumu et al., 2019). NC and BVDV are essential because they induce reproductive losses and have the propensity to cause persistent infections (Chernick et al., 2018).

Neospora caninum and bovine viral diarrhea virus have been reported as major causes of bovine abortion worldwide (Olum et al., 2020). There has been a hypothesis that both diseases have a synergism in inducing abortion, while there's no evidence to back this up (Konnai et al., 2008). This study aimed to investigate the association between BVDV and Neospora caninum infection as causes of abortion in cattle.

\section{MATERIALS AND METHODS}

\section{Animals:}

One hundred sixteen aborted cattle from 15 small to medium-sized cattle farms in different localities (Giza, El Fayoum and Beni Suef governorates). All the farms were vaccinated only with routine vaccination. The animals have a history of abortion. The abortion percentage in these farms ranged between 6 to $14 \%$. The aborted animals were from 3 to 8 years old. Most aborted cases were in the first trimester and the rest were in the second trimester.

\section{Sampling:}

One hundred sixteen serum samples were collected from 116 aborted cattle. Blood samples were collected by jugular venipuncture followed by centrifugation at $1500 \times \mathrm{g}$ for $10 \mathrm{~min}$. All sera were divided equally into two microtubes and stored at -20 ${ }^{\circ} \mathrm{C}$ until testing in the laboratory.

\section{Neospora Caninum Indirect ELISA:}

All 116 Serum samples were analyzed for antiNeospora antibodies were detected using an indirect ELISA ID. Vet kit (France). The manufacture instructions were followed when using kits. Read in an ELISA microplate reader at a wavelength of $450 \mathrm{~nm}$. For each sample, calculate the S/P percentage (S/P \%): The sample (OD $\left.{ }_{\text {sample }}\right)$ is divided by the mean positive control value (OD PC) multiplied by 100 .

$$
\mathrm{S} / \mathrm{P} \%=\frac{\mathrm{OD}_{\text {sample }}-\mathrm{OD}_{\mathrm{NC}}}{\mathrm{OD}_{\mathrm{PC}}-\mathrm{OD}_{\mathrm{NC}}} \times 100
$$

So if

Samples with an $\mathrm{S} / \mathrm{P} \%$ was $\leq 40 \%$ meant Negative while, if the sample was $40 \%<\mathrm{S} / \mathrm{P} \%<50 \%$, that told Doubtfully and if the sample was $\mathrm{S} / \mathrm{P} \% \geq 50 \%$, this meant positive.

\section{BVDV Sandwich ELISA:}

All 116 sera samples $(50 \mu 1)$ were submitted to BVDV antigen ELISA (ELISA BVDV-Ag) using (INGEZIM BVD DAS) kits. All procedures were performed according to manufacturing instructions. Briefly, ELISAs are carried out in solid-phase microplates. Wells are coated with anti-BVDV antibodies. Samples to be tested (serum) and controls are added to microwells. Anti-p80/p125 Biotin 
conjugated monoclonal antibodies (MAbs; conj.1) is added and subsequently, Streptavidin - peroxidase conjugate (conj.2) is added to each well. After washing, the substrate solution (TMB) is added and the optical density (OD) is read at $450 \mathrm{~nm}$. The tests can be considered valid if the ratios OD of the positive control/OD negative control $>10$.

\section{Results interpretation:}

Cut off $=$ OD of positive control $\times 0.1$

Samples with an OD higher than the cut-off value plus $15 \%$ must be considered as positive.

Samples with OD lower than the cut-off value minus $15 \%$ must be considered as negative.

Samples with OD values between both values (of positive and negative samples) are considered as doubtful. $\mathrm{S} / \mathrm{P}$ ratio was $\geq 0.2$

\section{Statistical analysis:}

The statistical analysis was carried out using the Chi-square test to examine the incidences of BVD, NC and Both BVD with NC among examined cattle serum samples using SPSS PC+ -Version 20.

\section{RESULTS}

The result showed that 66 of examined animals ( $\mathrm{N}=116)$ were positive to $\mathrm{BVDV}$ and/or $\mathrm{NC} 66$ $(56.9 \%)$, where the incidences of BVDV and $\mathrm{NC}$ were $31(26.72 \%)$ and $35(30.17 \%)$, respectively. There were $18(27.3 \%)$ samples that showed concurrent infection BVDV \& NC incidences among positive cow serum samples as shown in Fig (1).

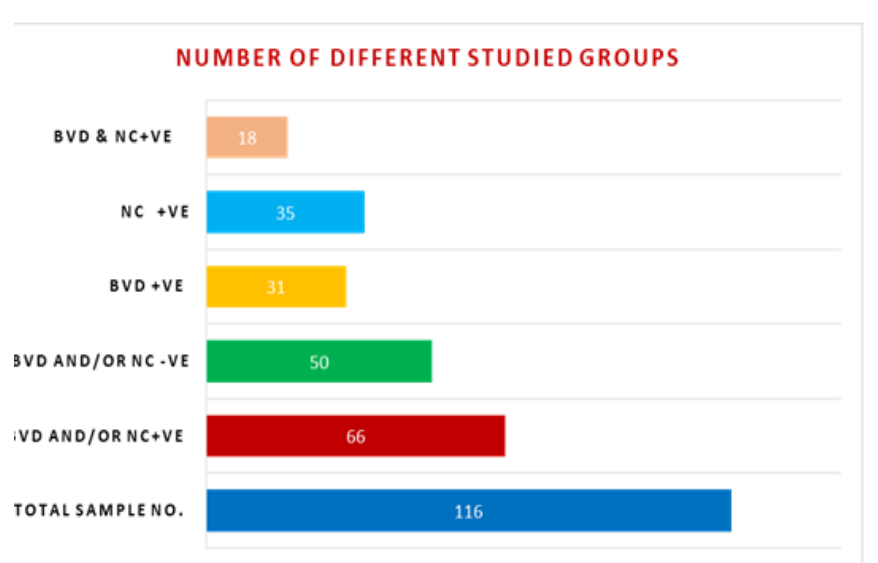

Fig. 1: Total number of different diagnosed sample groups.

\section{Incidence of bovine viral diarrhea virus:}

Results cleared that, the incidences of BVDV among examined cattle serum samples was 31(26.72 $\%$ ) and was (47\%) among +ve samples as in table (1).
Table 1: Incidences of bovine viral diarrhea among examined and positive samples using double sandwich ELISA.

\begin{tabular}{|c|c|c|c|}
\hline & \multirow{2}{*}{$\mathrm{N}$} & \multicolumn{2}{|c|}{ Positive } \\
\hline & & Numbers & $\%$ \\
\hline \multirow{2}{*}{ BVDV } & $\begin{array}{c}\text { Examined } \\
\text { samples } \\
\mathrm{N}=116\end{array}$ & 31 & 26.72 \\
\hline & $\begin{array}{c}\text { Positive } \\
\text { samples } \\
\mathrm{N}=66\end{array}$ & 31 & 47.00 \\
\hline
\end{tabular}

\section{Incidences of Neospora Caninum:}

Result cleared that, the incidences of $\mathrm{NC}$ among examined cattle serum samples was 35 $(30.17 \%)$ while it was (53\%) among +ve samples as seen in table (2).

Table 2: Incidences of Neospra caninum among examined and positive samples using indirect ELISA test.

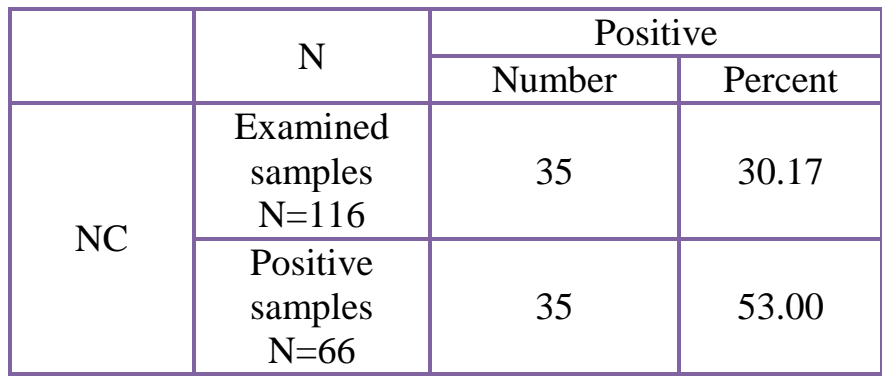

\section{Incidences of concurrent infection of Bovine viral diarrhea virus and Neospora caninum among positive samples. \\ Results cleared that, the concurrent} incidences of BVDV with NC among examined cattle serum BVDV and/or NC positive cases was $18(27.3 \%)$, and the concurrent infection percentage was $(15.52 \%)$ among total examined samples, as observed in table (3) and Fig.2.

Table 3: Incidences of concurrent infection among positive and total examined samples using ELISA test.

\begin{tabular}{|c|c|c|c|}
\hline & \multirow{2}{*}{$\mathrm{N}$} & \multicolumn{2}{|c|}{ Positive } \\
\cline { 3 - 4 } & & Number & Percent \\
\hline \multirow{2}{*}{$\begin{array}{c}\text { Concurrent } \\
\text { infection, } \\
\text { BVDV with } \\
\text { NC }\end{array}$} & $\begin{array}{c}\text { Examined } \\
\text { samples } \\
\mathrm{N}=116\end{array}$ & 18 & 15.52 \\
\cline { 2 - 4 } & $\begin{array}{c}\text { Positive } \\
\text { samples } \\
\mathrm{N}=66\end{array}$ & 18 & 27.3 \\
\hline \multicolumn{2}{|c}{} \\
\hline
\end{tabular}




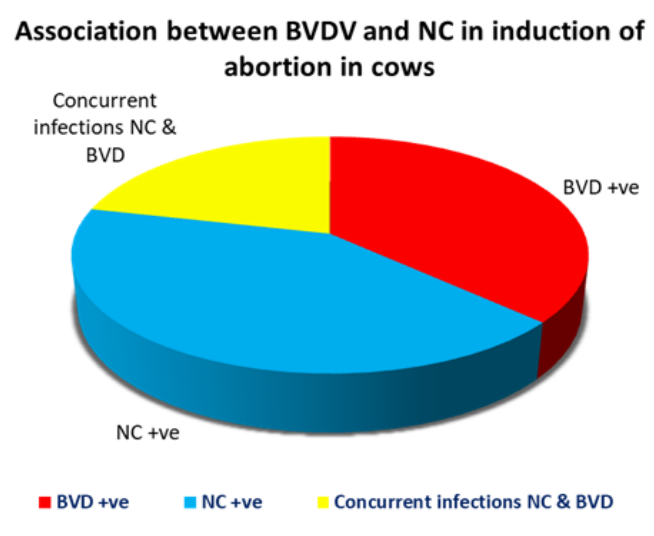

Fig. 2: Incidences of bovine viral diarrhea virus, Neospora caninum and concurrent infections (BVDV and NC) among examined positive samples.

4. Examination of the prevalence of BVD, NC, and concurrent infections in the serum samples of the cattle examined using Chi square test.

All the percentages related to the total number of samples (116) showed a high but non-significant relationship between BVDV and NC (Table 4) .

Table 4: Statistical examination of the incidences of BVD, NC, and concurrent BVD and NC among studied cattle serum samples.

\begin{tabular}{|c|c|c|c|}
\hline \multirow{2}{*}{ NC } & \multicolumn{2}{|c|}{ BVDV } & \multirow{2}{*}{ Total } \\
\cline { 2 - 3 } & Negative & Positive & \\
\hline Negative & $32(27.59 \%)$ & $31(26.72 \%)$ & $63(54.31 \%)$ \\
\hline Positive & $35(30.17 \%)$ & $18(15.51 \%)$ & $53(45.69 \%)$ \\
\hline Total & $67(57.75 \%)$ & $49(42.24 \%)$ & 116 \\
\hline $\begin{array}{c}\text { Chi- } \\
\text { square } \\
\text { test }\end{array}$ & \multicolumn{3}{|c|}{$2.74 \mathrm{~ns}$} \\
\hline P-value & \multicolumn{3}{|c|}{0.098} \\
\hline
\end{tabular}

\section{DISCUSSION}

The detection of Bovine Viral Diarrhea in the present study was done using a double-antibody sandwich immunoenzymatic assay that detects BVDV p80/p125 antigen. As high conserved immunogenic antigen in cytopathic (p80) or noncytopathic (p125) biotypes, it is well detected in PI animals' blood sera. Because of that, this test has formed the basis for successful eradication policies in many countries as a more rapid screening test and generating information on the infectious status. Also, Ag-ELISA showed a high sensitivity for detecting BVDV infected calves (Cornish et al., 2005).

Our results cleared that, the incidences of BVDV among examined cattle serum samples was 31(26.72
$\%)$. It was (47\%) among positive samples Table (1); these results were agreed with those of (El-Bagoury $\boldsymbol{e t}$ al., 2012), where they reported that the seroprevalence of BVD was $40 \%$ and $23 \%$ for cattle and buffaloes, respectively. Herd biosecurity strategies like disinfection, double fencing, and keeping a closed herd have been reported to diminish the prevalence of BVDV infection. (Kampa et al., 2004: Gates et al., 2013). BVDV infection of pregnant cows and heifers has been recorded as a cause of abortion and other reproductive abnormalities, as well as increased age at first calving and decreased ovarian function in affected herds, which could explain the widespread BVD infections and associated economic losses. (Kabongo and Van Vuuren, 2004; Heuer et. al., 2007). Bovine Viral Diarrhea Virus has also been reported to be fetopathogenic in cattle, thus leading to early embryonic death, repeat breeder syndrome, and abortion (Yang et al., 2012 and Yitagesu et al., 2021).

It was proved that all animals which have antibodies to Neospora spp are diagnosed as persistently infected (Bachofen et al., 2010) While the detection of BVDV virion or viral antigens indicates both acute infection (transiently infected animals - TI) and persistent infection (persistently infected animals PI) (Olum et al., 2020). Moreover, animals that are both serologically positive for Neospora spp. and positive for BVDV antigen in viral isolation or ELISAAg tests are thought to be co-infected by the two agents (Dubey et al. 2007). The coexistence of viruses and parasites should be linked to a number of epidemiological parameters, the most important of which is BVDV-induced immunosuppression (Melo $\boldsymbol{e t}$ al. 2004).

Our results showed that the incidence of $\mathrm{NC}$ among examined cattle serum samples was 35 (30.17 $\%$ ). In comparison, it was (53\%) among positive samples Table (2), these results were agreed with that recorded by (Dubey et al., 1998) where the prevalence of $N$. caninum antibodies were $68 \%$ and $20.43 \%$ in buffalo and cattle, respectively in the delta region in Egypt. Our results are higher than that reported by (Fereig et al., 2016), where they revealed that $18.9 \%$ of examined cattle were positive for N. caninum. Also, $\mathrm{NC}$ prevalence was high compared to other studies that had reported prevalence ranging from 1.9\%-39.7\% (Konnai et al., 2008; Asmare et al., 2013). This may be due to the low level of knowledge by farmers and animal health providers on abortion caused by animal health. Thus, the high prevalence of NC in this study may be associated with the low level of knowledge on this disease and the subsequent lack of a control program (Sarrazin et al., 2013), in addition to the role of stray dogs in Egyptian cattle farms. 
On other prospects, our results agreed with the results of (Fereig et al., 2016), where they reported a higher incidence of infection on small cattle farms compared with large farms; the incidences were $50.2 \%$ versus $37.8 \%$, respectively. They observed that cows in Sohag had a considerably greater prevalence than that in Qena, with a seroprevalence of $46.1 \%$ compared with $31.6 \%$, respectively. Pathogenesis of NC leads to abortions and fetal losses by inducing placental damage or causes the release of maternal prostaglandins that in turn cause luteolysis and abortion (Dubey et al., 2007 and Olum et al., 2020). The high seroprevalence recorded in this study indicates a high incidence of NC infections in cattle. These necessitates the application of more effective strategies for combating these types of infections on farms in Egypt.

Our results observed that, the concurrent incidences of BVDV with NC among examined cows serum samples was 18 (27.3\%) Table (3), this gives a clear illustration about the association between BVDV and Neospora caninum, that play role or may be involved in the induction of abortion in cattle where the percentages of concurrent infection were $(15.52 \%)$ among total examined samples. The statistical examination of BVD, $\mathrm{NC}$, and concurrent BVD and NC incidences among studied cattle serum samples showed a high but non-significant relationship between BVDV and NC, Table (4). These results agreed with (Quinn et al., 2004 and Lassen et al., 2012). They found a non-significant correlation between BVDV infection and Neospora spp. On the contrary, (Duong et al., 2008) found a significant association between $\mathrm{N}$. caninum and BVDV in small cattle farms. The high incidence rates of the $\mathrm{NC}$ and BVD was observed in their study (12.9\%); the most common cause of fetal loss was Neospora caninum (29.0\%), followed by mixed NC and BVDV infections of NC and BVDV (12.9\%), BVDV (9.9\%).

In addition, the 102 dairy cattle seropositive to Neospora caninum, 85 (83.3\%) were also seropositive to BVDV (Konnai et al., 2008; Okumu, 2014 and Okumu et al., 2019) reported similar findings in cattle herds with abortion; however, the biological impact of such coinfections requires further investigation. The concurrent infections had been thought to be due to the immunosuppressive effects of BVDV, increasing the chances of fetal infection by NC in pregnant cattle, thus increasing the chances of abortion. Previous studies have reported the consequences of concurrent $\mathrm{NC}$ and BVDV infections in cattle-producing abortion (Dubey and Schares, 2006; Yang et al., 2012). BVDV and N. caninum coinfection is reported in other studies and suggested that it should be related to higher rates of reproductive losses and, consequently, economic losses (Alves, et al., 2020).
The high incidence of BVDV 31 (26.72\%) and the high abortions coupled with NC $35(30.17 \%)$ in addition to BVD \& NC 18 (27.3\%) concurrent infection, Fig (1\&2) may be due to BVDV lead to immunosuppression that enhances subsequent infection by latent or other agents and contributes to the severity of infection (Yitagesu et al., 2021). NC might be a secondary cause of abortion and also may exacerbate abortion caused by other agents (Asmare et al., 2013).

The high level of seropositivity in this study may have been due to the lack of adequate control measures such as vaccination, screening and isolation of new introductions and improved biosecurity for these two diseases; this was probably due to lack of awareness of the presence of the conditions in dairy cattle in Egypt and consequently low levels of knowledge by the animal health industry players on the impact of these diseases (Asmare et al., 2013 and Fereig et al., 2016).

\section{CONCLUSION}

This study concluded that, the prevalence of BVDV and NC are high and widely spread in a cattle farm in Egypt. There is a high non-significant association between BVDV and NC and the concurrent infection present in more than a quarter of positive cases. So we should coordinate surveillance and a comprehensive policy on the control BVD and NC should be developed and implemented by the government with the involvement of all stakeholders in the dairy industry; laboratories should offer diagnostic tests for BVDV and NC to help farmers determine their roles in controlling abortions on their farms.

\section{Declaration of Conflicting Interests}

The authors revealed that there is no potential conflicts of interest.

\section{REFERENCES}

ALVES, M.E.M., FERNANDES, F., MONTEIRO, F.L., BRAUNIG, P.,CARGNELUTTI, J.F., FLORES, E.F., WEIBLEN, R., and VOGEL, F.S., 2020. Coinfection by Neopora caninum and bovine viral diarrhea virus in cattle from Rio Grande do Sul, Brazil, destined to exportation. Pesquisa Veterinária Brasileira, 40(8), 593-597.

ASMARE, K., REGASSA, F., ROBERTSON, L.J., and SKJERVE, E., 2013. Seroprevalence of Neospora caninum and associated risk factors in intensive or semi-intensively managed dairy and breeding cattle of Ethiopia.Veterinary Parasitology. 193. 85- 94. doi: 10.1016/j.vetpar.2012.11.025. Epub 2012 Nov 29. PMID: 23261087.

BACHOFEN C., BRAUN U., HILBE M., EHRENSPERGER F., STALDER H.P., and PETERHANS E., 2010. Clinical appearance and pathology of cattle persistently infected with bovine viral diarrhoea virus of different genetic subgroups. 
Vet. Microbiol. 141(3/4):258-267.doi: 10.1016/j.vetmic.2009.09.022. Epub 2009 Sep 25. PMID: 19819088 ; PMCID: PMC7117366.

CARPENTER, T.E., CHRIE,'L M., ANDERSEN, M., WULFSON, L., JENSEN, A., and HOUE, H. M., 2006. An epidemiologic study of late-term abortions in dairy cattle in Denmark, July 2000-August 2003. Preventive Veterinary Medicine. 77: 215- 229

CHERNICK, A., AMBAGALA, A., ORSEL, K., WASMUTH, JD, MARLE, G. VAN., and MEER, F. VAN., 2018. Bovine viral diarrhea virus genomic variation within persistently infected cattle. Infect. Genet. Evol. 58:218-223. doi: 10.1016/j.meegid.2018.01.002. Epub 2018 Jan 3. PMID: 29306002.

CORNISH, TE, VAN OLPHEN, A.L., and CAVENDER, JL., 2005. Comparison of ear notch immunohistochemistry, ear notch antigen-capture ELISA, and buffy coat virus isolation for detection of calves persistently infected with bovine viral diarrhea virus. J Vet Diagn Invest 17(2):110-117. doi: 10.1177/104063870501700203. PMID: 15825490.

DUBEY, J.P., and SCHARES, G., 2006. Diagnosis of bovine neosporosis. Veterinary Parasitology.140(12):1-34.doi: $\quad 10.1016 /$ j.vetpar.2006.03.035.PMID: 16730126 .

DUBEY, J.P., and SCHARES, G., 2011. Neosporosis in animals - the last five years. Vet. Parasitol. 180(1/2):90-108.doi: 10.1016/j.vetpar.2011.05.031. Epub 2011 May 27. PMID: 21704458.

DUBEY, J.P., ROMAND, S., HILALI, M., KWOK, O.C., and THULLIEZ, P., 1998. Seroprevalence of antibodies to Neospora caninum and Toxoplasma gondii in water buffaloes (Bubalus bubalis) from Egypt. Int. J. Parasitol. 28(3): 527-529.doi: 10.1016/s0020-7519(97)00190-2. PMID: 9559371.

DUBEY, J.P., SCHARES, G., and ORTEGA-MORA, L.M., 2007. Epidemiology and control of neosporosis and Neospora caninum. Clinical Microbiology Review. 20(2): 323-367.doi: 10.1128/CMR.00031-06. PMID: 17428888; PMCID: PMC1865591.

DUONG, MC., ALENIUS, S., HUONG, LT., and BJÖRKMAN, C., 2008 Prevalence of Neospora caninum and bovine viral diarrhoea virus in dairy cows in Southern Vietnam. Vet J. 175(3):390-4. doi: 10.1016/j.tvj1.2006.01.016. Epub 2007 Mar 8. PMID: 17349807.

EL-BAGOURY, GF, NAWAL, M.A., and KHADR, K.A., 2012. Prevalence of bovine viral diarrhea virus (BVDV) in cattle from some governorates in Egypt. Benha Vet. Med. J., 23: 123-130.

FEREIG, R.M., ABOULAILA, M.R., MOHAMED, SGA, MAHMOUD HYAH, ALI AO, ALI AF, HILALI, M., ZAID, A., MOHAMED, A.E.A., and NISHIKAWA, Y., 2016 .Serological detection and epidemiology of Neospora caninum and Cryptosporidium parvum antibodies in cattle in southern Egypt. Acta Trop. Oct;162: 206-211.doi: 10.1016/j.actatropica.2016.06.032. Epub 2016 Jul 1. PMID: 27377768.

GATES M.C., WOOLHOUSE, M.E., GUNN, G.J., and HUMPHRY R.W., 2013. Relative associations of cattle movements, local spread, and biosecurity with bovine viral diarrhea virus (BVDV) seropositivity in beef and dairy herds. Preventive Veterinary Medicine. 112(3-4):285-295.doi:

10.1016/j.prevetmed.2013.07.017. Epub 2013 Aug 14 PMID: 24012354

GONDIM, L.F. 2006. Neospora caninum in wildlife. Trends Parasitol. 22(6):247- 252.

HEUER, C., HEALY, A., and ZERBINI, C., 2007. Economic effects of exposure to bovine viral diarrhea virus on dairy herds in New Zealand. Journal of Dairy Science. 90(12):5428-38. doi: 10.3168/jds.2007-0258. PMID: 18024733

KABONGO, N., and VAN VUUREN, M., 2004. Detection of bovine viral diarrhea virus in specimens from cattle in South Africa and possible association with clinical disease. Journal of the South African Veterinary Association. $\quad 75 \quad$ (2): $90-93$.doi: 10.4102/jsava.v75i2.459. PMID: 15456165.

KAMPA, J., STÅHL， K., MORENO-LÓPEZ， J., CHANLUN, A., AIUMLAMAI, S., and ALENIUS, S., 2004. BVDV and BHV-1 infections in dairy herds in Northern and North-eastern Thailand. Acta Veterinaria Scandinavia. 45(3-4): 181-192. doi: 10.1186/1751-0147-45-181. PMID: 15663078; PMCID: PMC1820995

KOIWAI, M., HAMAOKA, T., HARITANI, M., SHIMIZU, S., ZENIYA, Y. ETO M., YOKOYAMA, R., TSUTSUI, T., KIMURA, K., and YAMANE, I., 2006. Nationwide seroprevalence of Neospora caninum among dairy cattle in Japan. Veterinary Parasitology. 135(2): 175-179.doi: 10.1016/j.vetpar.2005.08.014. Epub 2005 Oct 3 PMID: 16207513.

KONNAI, S., MINGAL, C.N., SATO, M., ABES, N.S., VENTURINA, A., GUTIERREZ, C.A., SANO, T., OMATA, Y., CRUZ ,C.L., ONUMA, M., and OHASHI, K., 2008. A survey of abortifacient infectious agents in livestock in Luzon, the Philippines, with emphasis on the situation in a cattle herd with abortion problems. Acta Tropica. 105(3):269-273. doi: 10.1016/j.actatropica.2007.12.004. Epub 2007 Dec 23. PMID: 18243149.

LASSEN, B., ORRO, T., ALEKSEJEV, A., RAAPERI K, JÄRVIS, T., and VILTROP, A., 2012 Neospora caninum in Estonian dairy herds in relation to herd size, reproduction parameters, bovine virus diarrhoea virus, and bovine herpesvirus 1. Vet Parasitol. 190(12):43-50. doi: 10.1016/j.vetpar.2012.05.021. Epub 2012 Jun 1. PMID: 22721941.

LINDBERG, A., and HOUE, H., 2005 Characteristics in the epidemiology of bovine viral diarrhea virus (BVDV) of relevance to control . Preventive Veterinary Medicine.72 (1-2). 55-73. doi: 10.1016/j.prevetmed.2005.07.018. Epub 2005 Oct 7. PMID: 16214248 .

MELO, C.B., LEITE, R.C., and LOBATO., Z.I., 2004 Infection by Neospora caninum associated with bovine herpesvirus 1 and bovine viral diarrhea virus in cattle from Minas Gerais state, Brazil. Vet. Parasitol. 119(2/3):97-105. doi 10.1016/j.vetpar.2003.12.002. PMID: 14746970. 
OIE World Organization of Animal Health, 2018. Manual of Diagnostic Tests and Vaccines for Terrestrial Animals.www.oie.int 8th ed. Paris: OIE; 2018. chapter 3.4.11. p. 1139-1157.

OLMO, L., DYE, MT, REICHEL, MP, YOUNG, JR, NAMPANYA, S., KHOUNSY, S., THOMSON, PC, WINDSOR, P.A., and BUSH, R.D., 2018. Investigation of infectious reproductive pathogens of large ruminants: Are neosporosis, brucellosis, leptospirosis and BVDV of relevance in Lao PDR? Acta Trop.; 177: 118-126. doi: 10.1016/j.actatropica.2017.10.007. Epub 2017 Oct 9. PMID: 29024616.

OKUMU, T. A. 2014. Infectious abortion and associated risk factors in dairy cattle farms in Nakuru district, Kenya. Ph. D. Thesis. Fac. Of Vet. Med. Clinical study. Dept. Niroub Univ. Kenya

OKUMU, T.A., JOHN, N.M., WABACHA, J.K., TSUMA, V., and VANLEEUWEN, J., 2019. Seroprevalence of antibodies for bovine viral diarrhea virus, Brucella abortus and Neospora caninum, and their roles in the incidence of abortion/foetal loss in dairy cattle herds in Nakuru District, Kenya. BMC Vet Res. Mar 18;15(1):95.doi: 10.1186/s12917-0191842-8. PMID: 30885192; PMCID: PMC6423779.

OLUM, M.O., MUNGUBE, E.O., NJANJA, J., KIDALI, J., NJENGA, E., MAICHOMO, M., TSUMA, V.T., and MUGAMBI, J., 2020. Seroprevalence of canine neosporosis and bovine viral diarrhea in dairy cattle in selected regions of Kenya. Transbound Emerg Dis. ;67 Suppl 2:154-158. doi: 10.1111/tbed.13429. Epub 2020 Jan 26. PMID: 31984679.

PAN, Y., JANSEN, GB, DUFFIELD, TF, HIETALA, S., KELTON, D., LIN, C.Y., and PEREGRINE, A.S., 2004. Genetic susceptibility to Neospora caninum infection in Holstein cattle in Ontario. Journal of Dairy Science. 87 (11). 3967-3975. doi: 10.3168/jds.S0022-0302(04)73537-7. PMID: 15483182.

PARADIES, P., CAPELLI, G., TESTINI, G, CANTACESSI, C., TREES, A.J., and OTRANTO, D., 2007. Risk factors for canine neosporosis in farm and kennel dogs in southern Italy. Veterinary Parasitology. $\quad 145 \quad$ (3-4):240-244.doi: 10.1016/j.vetpar.2006.12.013. Epub 2007 Jan 24. PMID: 17257762.

QUINN, H.E., WINDSOR, P.A., KIRKLAND, P.D., and ELLIS, J.T., 2004 An outbreak of abortion in a dairy herd associated with Neospora caninum and bovine pestivirus infection. Austr Vet J. 82(1-2):99-101. doi: 10.1111/j.1751-0813.2004.tb14656.x. PMID: 15088970 .

RADOSTITS, OM, LESLIE K.E., and FETROW J., 1994. Textbook of Herd Health; Food Animal Production Medicine.2nd edition. W.B.Saunders, Philadelphia, PA.

SARRAZIN, S., VELDHUIS, A., MÉROC, E., VANGEEL, I., LAUREYNS, J., DEWULF，J., CAIJ, A.B., PIEPERS, S., HOOYBERGHS, J., RIBBENS, S.. and VAN DER STEDE, Y., 2013. Serological and virological BVDV prevalence and risk factor analysis for herds to be BVDV seropositive in Belgian cattle herds. Preventive Veterinary
Medicine. 108(1) 28-37.

doi: 10.1016/j.prevetmed.2012.07.005. Epub 2012 Aug 9. PMID: 22878124.

SILVA, D., LOBATO, J., MINEO, T., and MINEO, J., 2007. Evaluation of serological tests for the diagnosis of Neospora caninum infection in dogs: Optimization of cut-off titers and inhibition studies of crossreactivity with Toxoplasma gondii. Veterinary Parasitology 143(3-4): 234-244.doi: 10.1016/j.vetpar.2006.08.028. Epub 2006 Sep 12. PMID: 16973287.

STÅHL, K., BJÖRKMAN ,C., EMANUELSON, U., RIVERA, H., ZELADA, A., and MORENOLOPEZ, J., 2006. A prospective study on the effect of Neospora caninum and BVDV on bovine abortions in a dairy herd in Arequipa, Peru. Preventive Veterinary Medicine 75(3-4): 177-188. doi: 10.1016/j.prevetmed.2006.02.006. Epub 2006 Apr 4. PMID: 16597470

WALDNER, C.L. 2005. Serological status for N. caninum, bovine viral diarrhea virus, and infectious bovine rhinotracheitis virus at pregnancy testing and reproductive performance in beef herds. Animal Reproduction Science. 90. 219-242.doi: 10.1016/j.anireprosci.2005.03.017. PMID: 15893892.

YANG, N., CUI, X., QIAN, W., YU S., and LIU, Q., 2012. Survey of nine abortifacient infectious agents in aborted bovine foetuses from dairy farms in Beijing, China, by PCR. Acta Veterinaria Hunguaria. 60. 8392. doi: 10.1556/AVet.2012.007. PMID: 22366134.

YITAGESU, E., JACKSON,W., KEBEDE, N., SMITH, W., and FENTIE, T., 2021. Prevalence of bovine abortion, calf mortality, and bovine viral diarrhea virus (BVDV) persistently infected calves among pastoral, peri-urban, and mixed-crop livestock farms in central and Northwest Ethiopia. BMC Vet Res.19;17(1):87. doi: 10.1186/s12917-021-02798-w. PMID: 33607976; PMCID: PMC7893777.

How to cite this article:

Rania S. El-Mohamady; Gerges, A.A., and Abd El-Hafeiz, Y.G.M., 2022. Investigation of The Association Between Bovine Viral Diarrhea Virus and Neospora caninum as a Cause of Abortion in Cattle. Journal of Applied Veterinary Sciences, 7 (1): $11-17$.

DOI:https://dx.doi.org/10.21608/javs.2021.98151.1106 